\title{
Hypopharyngeal Cancer pN2a TNM Finding v6 and v7
}

National Cancer Institute

\section{Source}

National Cancer Institute. Hypopharyngeal Cancer pN2a TNM Finding v6 and v7. NCI

Thesaurus. Code C64585.

Hypopharyngeal cancer with metastasis to a single ipsilateral lymph node, more than 3 $\mathrm{cm}$, but not more than $6 \mathrm{~cm}$ in greatest dimension. (from AJCC 6th and 7th Eds.) 